\title{
Geoøkonomi: \\ Nye læsere kan \\ begynde her
}

Af Mette Skak

De fleste husker nok Francis Fukuyama for hans lidt for kække afskrivning af historiens videre udvikling tilbage i 1989 i essayet 'The End of History'. Det gjorde ham berømt på den trælse herostratiske måde - som havde han brændt det altafgørende straffespark i en VMfinale. Derfor ved kun de færreste, at det virkeligt langtidsholdbare essay kom året efter - nemlig 'From Geopolitics to Geo-Economics. Logic of Conflict, Grammar of Commerce' (trykt i The National Interest, Summer 1990) - skrevet af den gamle hugaf, den rumænsk-amerikanske strateg Edward N. Luttwak.

Det er Luttwak, der har æren for at have udtænkt geoøkonomi som begreb for, når stater fører krig med andre midler for nu at citere titlen på en anden klassiker om geoøkonomi (Robert D. Blackwills og Jennifer M. Har- ris' bog War by Other Means fra 2016; her forkortet til $W b O M$ ).

I denne indføring i geoøkonomi præsenteres først Luttwaks teser, siden foldes viften ud med statskapitalisme og konkurrencestat som beslægtede begreber. Kritikken af Luttwak vil blive omtalt gennem den finske geoøkonom Antto Vihma fra The Finnish Institute of International Affairs i Helsinki. I skemaform præsenteres to bud på udbygninger af det geoøkonomiske begrebsapparat. Hele analysen krydres løbende med eksempler, der anskueliggør geoøkonomiens afgørende betydning som statslig praksis i det 21 . århundrede. For en ordens skyld vil jeg afslutningsvis søge at bøje denne pointe i neon.

Man skal huske på, at såvel Fukuyama som Luttwak skrev, mens Sovjetunionen, KGB og Warszawapagten endnu fandtes, og den kolde krig kun så småt gik på hæld. Derfor fortjener

Mette Skak er lektor ved Institut for Statskundskab, Aarhus Universitet. Hun har adskillige gange besøgt Rusland som led i sin forskning og er forfatter til utallige artikler og flere bøger. 
begge d'herrer respekt for i pagt med Karl Popper at vove pelsen med deres 'bold conjectures' vel vidende, at det kunne ende i lammende 'refutations'.

Kun Luttwak slap med skindet på næsen. Det skyldes antagelig, at han uden at sige det højt indleder med at give liberalismen ret $\mathrm{i}$, at koldkrigens ophør indvarsler en generel nedgang i de militære magtmidlers dominans i verdenspolitikken og en tilsvarende optur for de økonomiske magtmidler. Eller som han skriver. "... methods of commerce are displacing military methods" (s. 17). Geografien - de territoriale grænser og det statslige magtstræb, som de befordrer - vil derimod ikke forsvinde; derfor er det, at han smækker forstavelsen geo- på sin teori om økonomiens forrang i fremtidens internationale politik.

\section{Enten/eller}

Staten er kommet for at blive. Ergo kan geoøkonomi uden videre oversættes til økonomisk statskunst som allerede gjort af politologen David Baldwin i bogen Economic Statecraft fra 1985. Ham anser forfatterparret bag $W b O M$ for pioner.

Luttwak afviser, at nymerkantilisme skulle være en bedre betegnelse end geoøkonomi, for i merkantilismens storhedstid fra 1500-tallet og frem var krig mellem stormagterne altid en mulighed.

Så på den ene side holder Luttwak fast i, at Clausewitz har ret i at forstå krig som en måde at varetage interesser på; på den anden side gør Luttwak det til et paradigmeskift, at der efter Clausewitz og merkantilismen blev opfun- det atomvåben. De skabte en terrorbalance, der umuliggjorde krig mellem stormagter: “... for some decades now the dominant elites of the greatest powers ceased to consider war as a practical solution" (s. 21).

Luttwak forstår nærmest begrebsparret geopolitik (militær statslig rivalisering) og geoøkonomi ( $\varnothing$ konomisk statslig rivalisering) binært - som enten/eller - da 'the waning of the imperatives of geopolitics' er, hvad der karakteriserer nutiden og fremtiden (sammesteds). Så klar er langtfra alle. De fleste ser en dialektik mellem geopolitik og geoøkonomi, og Ukrainekrisen i 2014 fik mange til at slynge om sig med signalordet geopolitik - uden at forklare, hvad de lagde i det.

Om geoøkonomi understreger Luttwak, at der vil være stor forskel på staters evne og lyst til at agere geoøkonomisk. Vi befinder os jo i et univers af markedsøkonomier, hvor staten kun sidder på en brøkdel af det samlede $ø$ konomiske handlerum, påpeger han. Der vil være sameksistens mellem stat og erhvervsliv, undertiden et intenst, gensidigt fordelagtigt ('positivt') forhold, hvor magtfuldkomne erhvervslobbyer begunstiges af statsstøtte, og hvor bureaukrater og politikere manipulerer og tager sig godt betalt for deres ydelser.

Følgelig er geoøkonomi ikke lig økonomisk rationalitet. Der kan nemt gå korruption, fedt og snyd ikke bare flid i det globale geoøkonomiske spil. Sjældnere, men endnu mere sigende for geoøkonomien (som $W b O M$ ) ifølge Luttwak er de omvendte ('negative') relationer mellem stat og erhvervsliv. 
Når den geoøkonomiske rivalisering er intens, kan virksomheders patenterede teknologiske gennembrud blive udkonkurreret af visse staters vilje til aggressiv statsstøtte til samme teknologi på hjemmebane.

Det er, når stater går i åben handelskrig mod andre stater til skade for begges erhvervsliv, eller hvor uskyldige tredjelande og deres virksomheder kommer i klemme - som fx i trekantsdramaet mellem præsident Trumps USA og Kina, hvor EU er i skudlinjen.

Når den geoøkonomiske rivalisering er intens, kan virksomheders patenterede teknologiske gennembrud blive udkonkurreret af visse staters vilje til aggressiv statsstøtte til samme teknologi på hjemmebane. Læseren kan her indføje industrispionage som en nok så vigtig statslig geoøkonomisk praksis et felt, der ikke var nogen af de klassiske industrimagter fremmed i deres Gründerfase. Det skal vi lige huske, inden vores forargelse over Kina tager overhånd.

Det vidunderlige ved Luttwak er, hvor eftertænksom, nuanceret og fremsynet han er. Jo, han gør geopolitik og geoøkonomi til en art enten/eller til fordel for sidstnævnte, men det vil jeg forsvare som et forsøg på at gøre tilgangen falsificérbar og videnskabelig. På den måde bliver hans essay til en slagkraftig teori om, hvad ophøret af den kolde krig indebærer som det paradigmeskift, der bestemmer den verdensorden, vi nu lever $i$.

Netop dét er grunden til, at lige så kloge hoveder som Barry Buzan og George Lawson bruger ham som afsæt for deres bud på verdens beskaffenhed i lyset af globalisering og magtskifte (se deres 'Capitalism and the emergent world order' trykt i det britiske tidsskrift International Affairs, vol. 90, No. 1, 2014, s. 86 ff.). Nok så klogt slutter Luttwak med at skrive, at krig i geopolitisk dvs. militær forstand altid er ren nulsum og overlevelse, hvorimod økonomisk samkvem (commerce) sjældent er det.

Dermed lægger han op til, at intensiteten af krig, konfrontation og nulsumsspil faktisk kan gradbøjes i geoøkonomiens epoke. Han foregiber således Buzan og Lawsons samt andre politologers senere typologier og firefeltsskemaer (se nedenfor).

\section{Statskapitalisme og konkurrencestat} Ud over Luttwak er der en anden økonomisk klassiker, som læseren bør kende, når talen falder på geoøkonomi. Det er den tysk-amerikanske nationaløkonomiske reformtænker Friedrich List (1789-1846), der anså den britiske frihandelsdoktrin for at være et skalkeskjul for geoøkonomi uden at bruge ordet.

Storbritannien nød ifølge List så godt af dengang at have monopol på den industrielle revolution, at dets krav til USA om at afskaffe told på britiske varer var ensbetydende med at sparke stigen væk, når andre lande forsøgte at stige op. Det er List, der har æren for at genopdage merkantilismen, vel at mærke ikke som kolonirov og slavehandel, men derimod som legitimt nationaløkonomisk selvforsvar. Hans alternativ til frihandel var at tilråde 


\section{Selv om kommunismens sammenbrud betød ophøret af den sovjetiske planøkonomi med dens afsindige detailstyring, er den kapitalisme, der er trådt i stedet i Rusland og andre postkommunistiske økonomier, ingen laissez faire-kapitalisme baseret på minimalstaten.}

staten at indføre beskyttelsestold på varer produceret af industrier på kuvøsestadiet. Herved 'opfandt' List statens intervention i markedsøkonomien og foregreb statskapitalismen.

Statskapitalisme er atter blevet det nye sort, hvad angår modeller for samfundsøkonomiens indretning, og var temaet for en omfangsrig empirisk analyse i det britiske ugemagasin The Economist i 2012. Skoleeksemplet er naturligvis Kina med dets strategiske statsejede SOEs (State-Owned Enterprises), men stort set alle ulande og alle BRIKS-magter er mere eller mindre statskapitalistiske, og så er der jo vores Dong/Ørsted - fortsæt selv listen!

Selv om kommunismens sammenbrud betød ophøret af den sovjetiske planøkonomi med dens afsindige detailstyring, er den kapitalisme, der er trådt i stedet i Rusland og andre postkommunistiske økonomier, ingen laissez faire-kapitalisme baseret på minimalstaten.

Gennem statskontrol over olie- og gasmastodonterne har Putins Rus-

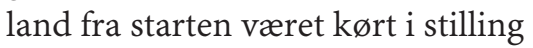
som geoøkonomisk aktør, om end det kan diskuteres, hvor stort held han har haft med sin statslige monopolkapitalisme (stamokap som det hed i DKP's særlige jargon); herom til sidst. For i virkeligheden er statskapitalisme kun undtagelsesvis en genvej til optimalt geoøkonomisk udbytte; det fremgår af Luttwak.

Snarere gælder det det liberale modtræk til den geoøkonomiske virkelighed. Her er det staten selv, der trimmes til at blive 'leaner, but meaner' under betegnelsen konkurrencestat (competition state). Herhjemme kendes professor Ove Kaj Pedersen som konkurrencestatens tænker, men æren bør retteligen gå til Philip G. Cerny.

Som læseren nok kan gætte, er vi nu fremme ved fænomener som djøfisering og New Public Management som dansk praksis udi geoøkonomisk kappestrid mellem staterne.

\section{Kritik af geoøkonomisk teori}

Måske fordi hverken det sidste eller de øvrige udlægninger af, hvad geoøkonomi går ud på, lyder særlig rare, findes der naturligvis kritik af tilgangen. Imidlertid er kritikken galt afmarcheret, som påpeget af finnen Vihma i et slagkraftigt forsvar for Luttwak ('Geoeconomic Analysis and the limits of Critical Geopolitics: A New Engagement with Edward Luttwak' trykt i 2018 i tidsskriftet Geopolitics, Vol. 23, No. 1, s. 1-21).

For det første er der den kritiske geopolitiker Ó Tuathail, der reducerer Luttwak til skråsikker realisme. Det uanset at Luttwaks prosa er spækket med de engelske ord for 


\section{9}

'fortrinsvis', 'fremherskende og 'tilbøjelighed' for at understrege, at han ikke taler om absolutter. Vigtigst af alt ifølge Vihma kan man læse Luttwak som et indlæg om indenrigspolitikkens betydning for hvilken geo$\varnothing$ konomisk strategi, staten lander på - ikke just hverdagskost blandt realister.

For det andet geografen Sparke, der insisterer på at fejllæse Luttwak som ren diskurs og ikke som et generelt bud på, hvordan stater faktisk agerer, når de handler strategisk - en teori, der skal stå sin prøve i virkeligheden. Sparkes kritik af Luttwaks fokus på staten ender i en irrelevant kobling til japaneren Ohmae.

For det tredje er der kritikere som Morrissey, der bruger Københavnerskolen til at bebrejde Luttwak, at han 'securitiser' sit genstandsfelt og dermed bidrager til den neoliberale (?!) mani med at gøre alt til sikkerhed, krig og overlevelse. Som det er fremgået, er det stik modsatte Luttwaks ærinde, eftersom han understreger, at kun krig og militær rivalisering handler om overlevelse og eksistentielle trusler - det som Københavnerskolens sikkerhedsbegreb hviler på. Mindre kan heldigvis gøre det inden for feltet geoøkonomi; dér er det netop ikke fokus på krig og nulsum hele vejen igennem - sådan afslutter Luttwak vitterlig sit essay.

Selv fornuftige folk som Guzzini går helt i selvsving ved mødet med Luttwaks modifikation af realismens konfliktoptik, forstår man på Vihma. Det preller helt af på Guzzini, når Putin og alskens russiske strategipapirer eksplicit benytter begrebet geoøkonomi og følger det op med aggressiv energi-geoøkonomi over for omverdenen.

Kritikken af Luttwak fremstår summa summarum langt mere enfol- dig end Luttwak gør. Dens ærinde er nærmest at tabuisere feltet geoøkono$\mathrm{mi}$, men intet kunne ligge redaktionen af Udenrigs fjernere!

\section{Varianter af geoøkonomi}

Som anført er Buzan og Lawson begejstrede for Luttwaks teori om geo$ø$ konomi som afsæt for, hvordan vi skal forstå det 21. århundredes globaliserede verden og den hertil svarende orden.

Ophøret af den kolde krig har vitterlig forandret og harmoniseret verden væk fra geopolitik og ideologisk konfrontation à la 1930. Kapitalisme er nu 'the only game in town', men den foreligger dels som en mere eller mindre autoritær statskapitalisme, dels som angelsaksisk laissez fairekapitalisme med socialdemokratisme/keynesianisme som den bløde mellemvare. Der er stadig forskelle i staters ressourcegrundlag, historie og geografiske vilkår; de giver forskelle $\mathrm{i}$ interesser, og hvad der udgør kloge 
valg af strategier. Følgelig kan Buzan og Lawson omsættes til nedenstående firefeltsskema:

Det er den bløde geoøkonomi, som forfatterne i deres udgivelsesår 2014 (Ukraine-kriseåret) gør til deres bud på logikken i en Kina-præget verdensorden. De ser i ramme alvor en mulig koncert med moderation i forholdet mellem stormagterne.

Hvad angår den bløde geoøkonomi som mellemform mellem $W b O M$ og gensidigt fordelagtige økonomiske forhold mellem stater, er det værd at indskyde en vigtig indsigt fra WbOM-bogen s. 24-25. Nemlig, at win win-tilstande forudsætter, at staten har rent $\varnothing$ konomiske endemål som grundlag i sin geoøkonomiske strategi. Med andre ord må geoøkonomien ikke alene dreje sig om statens valgte midler, som det typisk er tilfældet.

Der findes et andet begreb for stater, der praktiserer den mere godmodige geoøkonomi, nemlig Peter Evans' begreb developmental state/ udviklingsstat, der bruges om de indenrigspolitisk hårde dvs. handlekraftige stater i Østasien, som i tiden efter
Anden Verdenskrig trak sig selv op ved hårene - lande som Japan og Sydkorea. Dvs. stater, der har taget List til sig i en klog og dynamisk balance mellem stat og marked, og som i tide tog skridtet væk fra protektionisme over mod eksportdrevet vækst.

Man kan afgjort også fortolke Kina som udviklingsstat, hvorimod det er mere usikkert, om betegnelsen gælder de fire andre BRIKS-magter, for dér kniber det med den rettidige omhu.

Som det indirekte fremgår af Luttwak, når han insisterer på at skelne mellem staters lyst og forudsætninger for at gå geoøkonomisk til værks, må man logisk set forvente af småstater, at de holder sig til en forsigtig og blød geoøkonomi, der undlader at udfordre alfahannerne.

Sådan kan man forstå Tibet-skandalen herhjemme. Ligeledes Bjarne Corydons famøse salg af Dong-aktier til Goldman Sachs, der ikke trådte andre over tæerne end det samlede danske politiske establishment samt utallige debattører og læserbrevsskribenter. Det var vist tænkt som uskyldig kurspleje og bæredygtig energi-

SKEMA 1: Buzan \& Lawsons bud på varianter af geopolitik og geoøkonomi:

\begin{tabular}{|c|c|c|}
\hline & Geopolitik & Geoøkonomi \\
\hline Hård & $\begin{array}{l}\text { Krig mellem stormagter anses for } \\
\text { legitim og forventelig, da international } \\
\text { politik er et nulsumsspil og magtstræbet } \\
\text { ubehersket. }\end{array}$ & $\begin{array}{l}\text { Konkurrencen om markeder, } \\
\text { økonomiske konflikter osv. er et } \\
\text { nulsumsspil. Staten ønsker at øge sin } \\
\text { magt på bekostning af andre stater }\end{array}$ \\
\hline Blød & $\begin{array}{l}\text { Krig mellem stormagter er nærmest } \\
\text { udelukket. Dog ses militær rivalisering } \\
\text { og balancering af den stærke. }\end{array}$ & $\begin{array}{l}\text { En blanding af nulsumsspil og winwin } \\
\text { i samspillet mellem staterne og deres } \\
\text { nationaløkonomier. }\end{array}$ \\
\hline
\end{tabular}


geoøkonomi for, at Dongs havmøller kunne få luft under vingerne med hjælp fra alverdens øvrige investorer. Uanset Goldman Sachs' obskøne kursgevinst burde aktiesalget måske alligevel ses i lyset af vikingernes forretningsmodel: 'tax all foreigners living abroad'.

Hvad angår det anderledes krigeriske potentiale i, når staten 'kun' bruger geoøkonomi som instrument, vil jeg citere Blackwill og Harris: “[... ] when put to geopolitical use, economic instruments can produce outcomes that are every bit as powerful and as zerosum as those resulting from traditional military showings of state power" ( $W b O M$, s. 25). Det oplagte eksempel er her de ofte latterliggjorte økonomiske sanktioner, som EU og USA under præsident Obama gjorde til det vestlige svar på Ruslands angreb på Ukraine i 2014.

Vi ved, at det ligger Kreml meget på sinde at få dem væk; det ønske er et sandsynligt supplerende motiv bag den chokerende russiske indblanding i det amerikanske valg i 2016. I hvert fald ved vi, at Trump er servil over for
Putin og kritisk over for sanktionerne. Med disse betragtninger i lyset af Buzan og Lawson samt Luttwak selv vil jeg præsentere de finske geoøkonomers endnu bredere typologi over mulige varianter. Konkret vil jeg gengive det firefeltskema, der er udviklet af Mikael Wigell (se hans 'Conceptualizing regional powers' geoeconomic strategies: neoimperialism, neomercantilism, hegemony, and liberal institutionalism', trykt i 2016 i Asia-Europe Journal, 14, s. 135-151). For selv om forfatteren står i ental, drejer det sig om kollegaen til Vihma, der sammen med ham har udgivet flere glimrende bidrag til geoøkonomisk forskning om EU, Rusland og sanktionerne.

Typologien tager sigte på at gøre læseren opmærksom på, at geoøkonomi udspiller sig uhyre forskelligartet i de forskellige regioner på jordkloden; ergo et bidrag, der tager forstavelsen 'geo' i ordet geoøkonomi ekstra alvorligt som påmindelse om jordklodens mangfoldighed.

Pointen i denne typologi er at tydeliggøre, at man udmærket kan forestille sig en rendyrket liberal geoøkono-

SKEMA 2: Mikael Wigells bud på mulige varianter af geoøkonomi:

\begin{tabular}{|l|l|l|}
\hline & $\begin{array}{l}\text { Rivalisering som statens strategiske } \\
\text { kultur/instinkt }\end{array}$ & $\begin{array}{l}\text { Samarbejde som statens strategiske } \\
\text { kultur/instinkt }\end{array}$ \\
\hline $\begin{array}{l}\text { økonomisk } \\
\text { magt som mål }\end{array}$ & $\begin{array}{l}\text { Nymerkantilisme } \\
\text { geoøkonomi i Luttwaks } \\
\text { nulsumsforstand: } \\
\text { interessevaretagelse til skade for } \\
\text { den økonomiske modpart. }\end{array}$ & $\begin{array}{l}\text { Liberal institutionalisme } \\
\text { geoøkonomi som en måde } \\
\text { at varetage interessen i det } \\
\text { fælles bedste på [så såkaldt } \\
\text { Paretooptimale udfald nås]. }\end{array}$ \\
\hline $\begin{array}{l}\text { Økonomisk } \\
\text { magt som } \\
\text { instrument }\end{array}$ & $\begin{array}{l}\text { Nyimperialisme } \\
\text { når målet bag den geoøkonomiske } \\
\text { fremfærd er at oprette et imperium } \\
\text { i den pågældende stats nabolag. } \\
\text { Tvang bruges. }\end{array}$ & $\begin{array}{l}\text { Hegemoni } \\
\text { geoøkonomi, der afstår fra brugen } \\
\text { af tvang, idet målet blot er at opnå } \\
\text { en lederposition i regionen - ofte ved } \\
\text { at betale gildet. }\end{array}$ \\
\hline
\end{tabular}




\section{EU er derimod skoleeksemplet på en hegemonisk aktør, der har givet lande som Hviderusland ekstra elastik i grel kontrast til Ruslands bryske fremfærd uanset unionen med Hviderusland.}

mi, navnlig hvis Luttwak holder stik, så militære opgør mellem stormagterne i form af skydekrige er fortid. I så fald behøver staterne ikke længere holde krudtet tørt, men kan kanalisere deres energi i mere opbyggelige retninger.

Men ligesom Vihma i sit forsvar for Luttwak nægter Wigell at udelukke realismens varianter af destruktiv geo$\varnothing$ konomisk adfærd uden, at det hermed skal hedde sig, at geoøkonomerne 'securitiser' international politik.

Som eksempel på realismens to varianter nævner Wigell for nymerkantilismens vedkommende de såkaldte handelsstater Japan og Tyskland efter nederlaget i Anden Verdenskrig samt nutidens Brasilien, der er en af de mest protektionistiske stormagter, hvad importtold angår. Som eksempel på en nyimperialistisk magt fremhæver han Putins Rusland, der over for sine svage postsovjetiske naboer tyr til både økonomisk magtanvendelse, tvang, påtvingelse og bestikkelse. Ruslands trumfkort over for nabolaget er landets energigeoøkonomiske evne.

EU er derimod skoleeksemplet på en hegemonisk aktør, der har givet lande som Hviderusland ekstra elastik i grel kontrast til Ruslands bryske fremfærd uanset unionen med Hviderusland. Den så at sige spejderdrengsagtige liberalt institutionelle geoøkonomi repræsenteres af vor nabo Tyskland ifølge de finske geoøkonomer. Efter Anden Verdenskrig lagde Tyskland i den grad bånd på sig selv trods landets industrielle råstyrke og formidable evne til innovation. Den underspillede slagkraft personificeres af kansler Angela Merkel, der balancerer mellem realisme og liberale instinkter for at det, der er værre, ikke skal tage over her i Europa.

\section{Kommet for at blive}

Undervejs har jeg krydret analysen med konkrete eksempler på, hvordan stater agerer geoøkonomisk, så vi har været næsten hele kompasset rundt: Fra de hårde udviklingsstater i Østasien, der har taget List og den tyske selvdisciplin til sig, til Det Vilde Vesten eller med andre ord Trumps handelskrige, der bringer EU i klemme og anskueliggør en facet i analysen hos geoøkonomiens ophavsmand Luttwak. Fra Danmark i nord, der som småstat ifølge mange lavede et geoøkonomisk selvmål med salget af Dong-aktierne, til Brasilien i syd, der også ifølge mange laver geoøkonomiske selvmål med sin stædige beskyttelsestold af de særdeles voksne og bogstavelig talt flyvefærdige industrier (flyfabrikken Embraer tjener kassen globalt).

Så jeg løber antagelig åbne døre ind med budskabet om, at geoøkonomien er kommet for at blive og derfor et tema i Udenrigs værdig. Ellers vil jeg tilføje, at The Economist for nylig havde en forside og en indgående empirisk analyse, der skulle anskueliggøre, at vi af geo$ø$ konomiske grunde lever i en Kina-styret verden 'Planet China. What to make 
of the Belt and Road Initiative' (July 28th-August 3rd) - det, der også kendes som Kinas Silkevejsprojekt.

Skulle nogen indvende, at klimaforandringerne da er en endnu mere altomfattende strategisk trussel at forholde sig til, vil jeg for det første give dem ret! For det andet vil jeg tilføje, at geo$ø$ konomi og - skal vi kalde det geoøkologi - men altså klimaforandringerne på det politiske handlingsplan vil være sært forbundne kar - ligesom geopolitik og geoøkonomi.

\section{Rusland}

Jeg vil som lovet slutte med at kommentere på den geoøkonomi, jeg kender mest til, nemlig Rusland. For sandt er det jo, at Putin på et tidligt tidspunkt sprang ud som statskapitalist og geoøkonom og søgte at realisere en generelt hegemonisk, men regionalt nyimperialistisk geoøkonomisk strategi (herom se mit kapitel om Rusland i bogen Fremtidens stormagter. BRIK'erne $i$ det globale spil redigeret af mig og udgivet i 2010 på Aarhus Universitetsforlag).

Det er som om den russiske gas- og oliesupermagt er sprunget op som en løve for så at falde ned som et lam. Det skyldes de stagnerende olie- og gaspriser, hvortil kommer Putins tilflugt til hård geopolitik i Buzan og Lawsons forstand over for Ukraine. Det fik som ovenfor nævnt Vesten til at svare igen med hård geoøkonomi i form af $ø$ konomiske sanktioner, der yderligere indskrænkede Kremls handlerum.

Efter Putins magtdemonstrationer i Ukraine og Syrien er lysten til at binde sig til hans gashaner gennemgående ik-

\section{Det er som om den russiske gas- og oliesupermagt er sprun- get op som en løve for så at falde ned som et lam.}

ke stor. Selv om projektet muligvis realiseres, bliver det formentlig på vilkår til fordel for det svage Ukraine.

Som man forstår på det ovenfor omtalte bidrag af Vihma, udgør Rusland et paradoks i og med, at russerne var blandt de første til at tage Luttwaks tilgang til sig og gøre den til deres egen. Modsat den liberale spejderdreng Fukuyama var Luttwaks budskab vand på russernes mølle.

Alligevel lå det ikke i kortene, at Rusland kunne træde i karakter som verdens geoøkonomiske stormagt. For i det større historiske perspektiv er Rusland en stormagt i økonomisk forfald - en 'declining', ikke en 'rising power' med de engelske fagudtryk. Det har Putin ikke ændret på, men han har kompenseret for sit hjemlands forfald ved en storpolitisk genistreg, bemærker den britiske analytiker Mark Leonard ('What does Russia think?', Prospect Magazine, 20th October, 2010).

Genistregen er effektivt at skjule sit hjemlands forfald ved at skrue op for nationalismen og give Rusland en sexet identitet som BRIKS-magt og således placere landet i slipstrømmen på Kinas fremgang. Russerne er, som det er fremgået, heller ikke blege for at gøre sig forhadte i nabolaget eller digitalt lave rav i den længere væk som vej til 'storhed'. 